\title{
Ceftezole, a cephem antibiotic, is an $\alpha$-glucosidase inhibitor with in vivo anti-diabetic activity
}

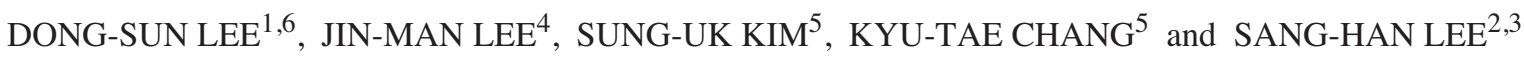 \\ Departments of ${ }^{1}$ Microbiology, ${ }^{2}$ Food Science and Technology, ${ }^{3}$ Food and Bio-industry Research Institute, \\ Kyungpook National University, Daegu 702-701; ${ }^{4}$ Department of Herbs and Food Science, Kyongbuk College of \\ Science, Chilgok 718-850; ${ }^{5}$ Korean Research Institute of Bioscience and Biotechnology (KRIBB), Daejeon 305-333, Korea
}

Received January 29, 2007; Accepted March 12, 2007

\begin{abstract}
Using a high throughput-compatible assay to screen for potential $\alpha$-glucosidase inhibitors, we found that the $\beta$-lactam antibiotic ceftezole exhibited potent $\alpha$-glucosidase inhibitory activity. In in vitro $\alpha$-glucosidase assays, ceftezole was shown to be a reversible, non-competitive inhibitor of yeast $\alpha$-glucosidase with a $\mathrm{K}_{\mathrm{i}}$ value of $5.78 \times 10^{-7} \mathrm{M}$ when the enzyme mixture was pretreated with ceftezole. Using an in vivo streptozotocin-induced mouse model, we confirmed that blood glucose levels decreased by $30 \% 20 \mathrm{~min}$ after ceftezole treatment $(10 \mathrm{mg} / \mathrm{kg} /$ day $)$. Expression levels of glycogen synthase kinase-3, peroxisome proliferator-activated receptor- $\gamma$, and uncoupling protein-3 mRNA were also slightly decreased compared to controls following ceftezole treatment. Taken together, these in vivo and in vitro results suggest that ceftezole may be a clinically useful anti-diabetic compound.
\end{abstract}

\section{Introduction}

Diabetes, which is one of the most severe metabolic disorders in humans, is characterized by hyperglycemia as a result of a relative or an absolute lack of insulin or insulin activity on target tissue, or both (1). Diabetes is actually a heterogeneous

Correspondence to: Professor Sang-Han Lee, School of Life and Food Science, Kyungpook National University, Daegu 702-701, Korea

E-mail: sang@knu.ac.kr

Present address: ${ }^{6}$ Department of Biochemistry and Molecular Biology, University of Texas, TX 77030, USA

Abbreviations: IDDM, insulin-dependent diabetes mellitus; NIDDM, non-insulin-dependent diabetes mellitus; STZ, streptozotocin; RT-PCR, reverse transcriptase-polymerase chain reaction; PTP-1B, protein-tyrosine phosphatase-1B; GAPDH, glyceraldehyde-3-phosphate dehydrogenase; UCP-3, uncoupling protein-3; GSK-3, glycogen synthase kinase-3; PPAR- $\gamma$, peroxisome proliferator-activated receptor- $\gamma$

Key words: ceftezole, $\alpha$-glucosidase, inhibitor, in vitro, in vivo, anti-diabetic group of metabolic disorders caused by both genetic and environmental factors that result in glucose intolerance (2). It originates from a biochemical imbalance in the pancreatic $\beta$-cell environment and is caused by mutations in a variety of genes, suggesting that the majority of diabetic disorders are multifactorial. Diabetic disorders are classified into two major groups: type 1 or insulin-dependent diabetes mellitus (IDDM), and type 2 or non-insulin-dependent diabetes (NIDDM) (3). Type 1 diabetes represents $\sim 2-5 \%$ of all cases, and the major susceptibility gene for IDDM maps to the HLA region of chromosome 6 , while type 2 diabetes represents $\sim 95 \%$ of all cases and affects $\sim 215$ million people worldwide $(4,5)$. Both forms of diabetes are associated with major long-term complications, including cardiomyopathy, angiopathy, neuropathy, nephropathy, and digestive insufficiencies. IDDM is caused by auto-immune destruction of pancreatic B-cells, which renders the pancreas unable to synthesize and secrete insulin (6). For the majority of IDDM and NIDDM cases, the precise biochemical defects, genetic causes, and other contributing factors are not fully understood (7).

Here, we present data indicating that ceftezole exhibits both in vitro $\alpha$-glucosidase inhibition activity and in vivo streptozotocin (STZ)-induced diabetic activity. We identified ceftezole using a high throughput-compatible $\alpha$-glucosidase assay and verified its effectiveness by performing an oral glucose tolerance test in STZ-induced diabetic mice and RTPCR of their blood cells. These data suggest that ceftezole has potential as an anti-diabetic drug.

\section{Materials and methods}

Reagents. $\alpha$-Glucosidase (from bakers yeast), $\beta$-glucosidase (from almond), $\alpha$-mannosidase (Jack beans), and ß-mannosidase (from snail acetone powder), $p$-nitrophenyl (PNP) glycosides, and streptozotocin were purchased from Sigma Chemical Co. (St. Louis, MO). Ceftezole and GlucoDoctor were obtained from KyungBo Chemical (Seoul, Korea) and All Medicus (Seoul, Korea), respectively.

High throughput-compatible $\alpha$-glucosidase assays. To screen agents that potently inhibit various commercially available glycosidases, a high-throughput enzyme assay was performed as described previously with a slight modification (8) (data 
not shown). The high throughput-compatible assay was performed using a CyBi-Well 2000 liquid handler (CyBio, Jena, Germany) and a Victor2 multi-label counter (Wallac, Turku, Finland). In brief, $\alpha$-glucosidase and the other glycosidases were assayed using $50 \mathrm{mM}$ phosphate buffer at pH 6.7, and $1 \mathrm{mM}$ p-nitrophenyl glycoside in a 96-well plate was used as a substrate. The concentration of enzymes used in each experiment is described in the figure legends. Ceftezole at the designated concentrations was added to the enzyme/ buffer solution and incubated at $30^{\circ} \mathrm{C}$ for $1 \mathrm{~h}$, and the substrate was then added to start the enzyme reaction. When pretreatment was not specified, mixtures of substrate and ceftezole at various concentrations were prepared beforehand and added to the enzyme solution. Enzyme reactions were performed at $30^{\circ} \mathrm{C}$ for $30 \mathrm{~min}$, and $3 \mathrm{vol}$ of $1 \mathrm{M}$ sodium carbonate were then added to stop the reaction. The total reaction volume was $100 \mu 1$. Enzymatic activity was quantified by measuring the absorbency at $405 \mathrm{~nm}$. One unit of $\alpha$-glucosidase and other glycosidases is defined as the amount of enzyme liberating 1.0 $\mu$ mole PNP per min under the assay conditions. The high throughput-compatible protocol, which consisted of 80 steps using the liquid handler was performed with a slight modification as described in the manufacturer's manual (CyBio). After liquid handling in each well, plates were transferred to the multilabel counter to measure the optical density using a robotic arm (Thermo CRS, Burlington, Canada).

Kinetics of enzyme inhibition. The enzyme reaction was performed according to the above reaction conditions with inhibitors at various concentrations. Inhibition strengths for the inhibitors were determined by Dixon plot and its replot of slope versus the reciprocal of the substrate concentration (9).

$R N A$ preparation and $R T-P C R$. Total cellular RNA was extracted from blood cells using the TRIzol reagent (Gibco BRL, Grand Island, NY). cDNAs were synthesized from $1 \mu \mathrm{g}$ total RNA using Oligo(dT) reverse transcriptase (iNtRON Biotechnology, Sungnam, Korea) and were PCR-amplified with specific primers: mouse aldose reductase (496-bp long) forward, 5'-ATC TGG AAC TCA ACA ACG GC-3' and reverse, 5'-CCT CTC AAT CTG AAG AGG GT-3'; GSK-3 (996-bp long) forward, 5'-GAG GAG CTA TCT TCG GAT AG-3' and reverse, 5'-GCG TTC CTA GTA CCT TGA TG3'; PPAR- $\gamma$ (532-bp long) forward, 5'-CCA CTC GCA TTC CTT TGA CA-3' and reverse, 5'-TCA GCT GGT CGA TAT CAC TG-3'; PTP-1B (633-bp long) forward, 5'-CGG AAC AGG TAC CGA TAT GT-3' and reverse, 5'-GCA TCT CCA GCA GTA CTT TC-3'; and UCP-3 (659-bp long) forward, 5'GAA GCA AAA GATT GCC AGG C-3' and reverse, 5'CAC CAT CTC AGC ACA GTT GA-3'. GAPDH (371-bp long) forward 5'-ATG TTC CAG TAT GAC TCC AC-3' and reverse, 5'-GCC AAA GTT GTC ATG GAT GA-3' was used as an internal control. The resulting PCR products were analyzed by $1.2 \%$ TAE agarose gel electrophoresis and visualized by ethidium bromide staining.

Streptozotocin exposure and diabetic mice. Diabetes was induced by intravenous STZ injections $[30 \mathrm{mg} / \mathrm{kg}$ in freshly prepared $10 \mathrm{mM}$ sodium citrate buffer $(\mathrm{pH} 4.5)]$ into veins of

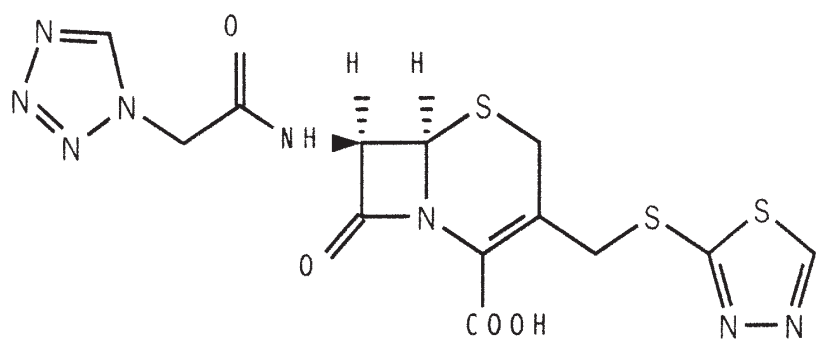

Figure 1. Structure of ceftezole.

mice in one diabetic control group and one treatment group (10). Diabetic female mice (C57BL/6Nkist) were identified as those having blood glucose levels $>250 \mathrm{mg} / \mathrm{dl}$ using a GlucoDoctor kit. After 20 days of STZ injections, we confirmed that diabetic mice $(\mathrm{n}=10)$ exhibited significantly increased blood glucose levels $(266.7 \pm 15.8 \mathrm{mg} / \mathrm{dl})$ compared with the control mice $(104.1 \pm 12.9 \mathrm{mg} / \mathrm{dl})$. Ceftezole or vehicle (distilled water) was given intraperitoneally $(30 \mathrm{mg} / \mathrm{kg} /$ day $)$ every day for 14 days. Twenty-four hours after the final ceftezole treatment, mice were anesthetized with pure diethyl ether inhalation, and blood analysis was carried out. Tissues were collected for RT-PCR. Remaining mice were subjected to an oral glucose tolerance test. Animal husbandry and experimentation were performed in compliance with the Guiding Principles in the Care and Use of Animals and the Animal Welfare Committee of the Korean Research Institute of Bioscience and Biotechnology (KRIBB). C57BL/6NKist mice were housed in specific pathogen-free (SPF) barrier facilities of KRIBB, a sub-center of the International Council for Lab Animal Science (ICLAS; code no. Kist). All mice were fed Purina rat chow (\#5012, Harlan, Indianapolis, IN) and water ad libitum. Animals were maintained in a room under standard laboratory conditions $\left(23 \pm 1^{\circ} \mathrm{C}\right.$ and $50 \pm 5 \%$ humidity) with a $12 \mathrm{~h} / 12 \mathrm{~h}$ dark/light cycle. Animal care guidelines and rules for animal experiments, including ethical care, were strictly followed under the guidance of the committee.

Oral glucose tolerance test. Oral glucose tolerance was tested with a slight modification of the protocol described previously (11). Briefly, 20 days after STZ exposure, animals underwent an oral glucose tolerance test (OGTT). The oral blood glucose concentration was determined using the GlucoDoctor glucose testing system based on a glucose oxidase assay.

\section{Results}

High throughput-compatible screening. While screening potential $\alpha$-glucosidase inhibitors from various sources, we developed a high throughput-compatible assay protocol for $\alpha$-glucosidase inhibition (data not shown). Using this protocol, we tested $\sim 11,800$ chemicals and 1,450 unfractionated plant extracts. As a result, we isolated and identified the B-lactam antibiotic ceftezole as a potential $\alpha$-glucosidase inhibitor (Fig. 1 and data not shown).

Ceftezole inhibits $\alpha$-glucosidase in vitro. Of the enzymes tested, $\alpha$-glucosidase was the most sensitive to ceftezole; the 

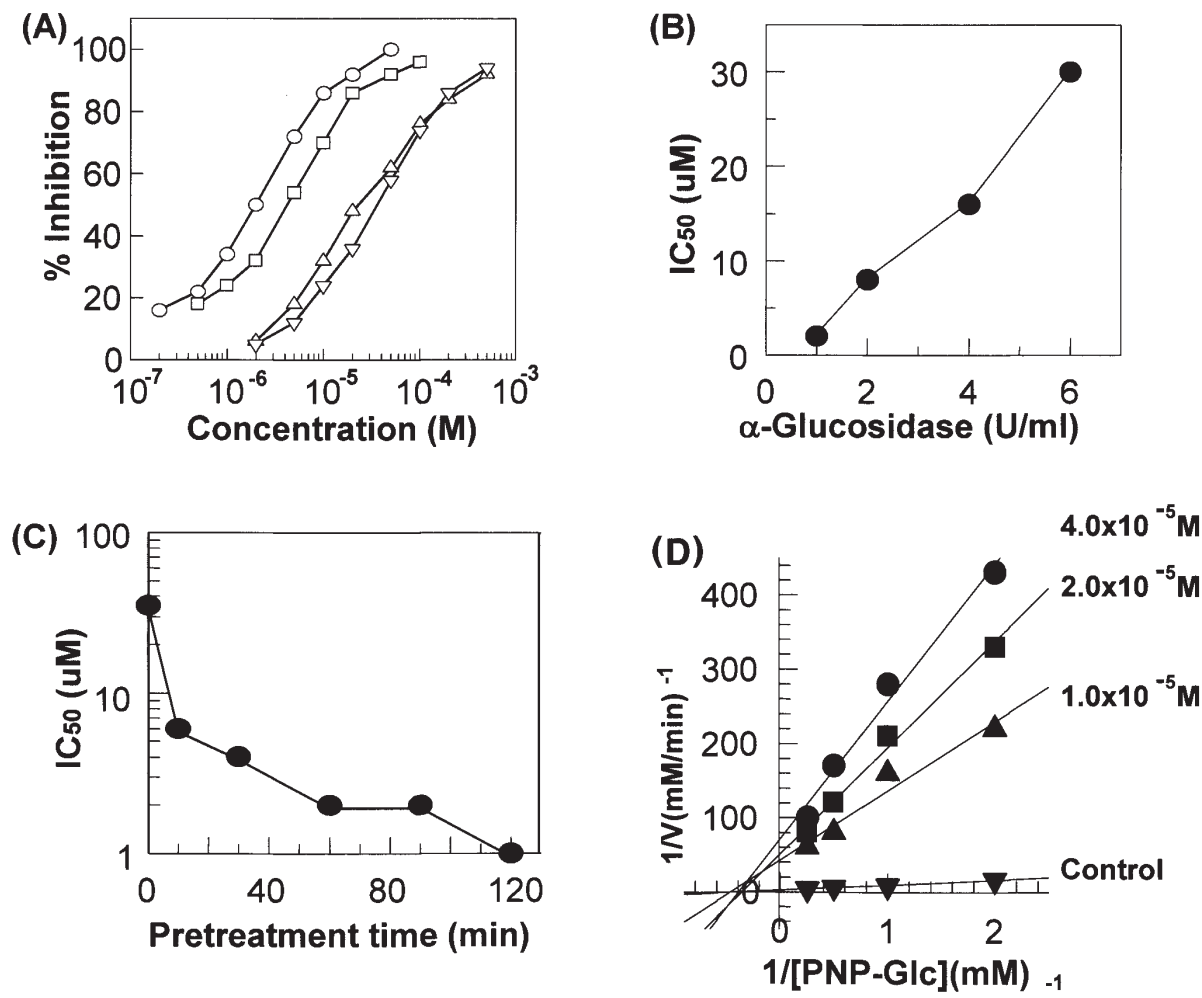

Figure 2. Ceftezole is an $\alpha$-glucosidase inhibitor in vitro. (A) Inhibition of various glucosidases by ceftezole. Enzyme solutions were treated with various concentrations of ceftezole: $1 \mathrm{U} / \mathrm{ml} \alpha$-glucosidase $(0), 0.5 \mathrm{U} / \mathrm{ml} \beta$-glucosidase $(\nabla), 0.5 \mathrm{U} / \mathrm{ml} \alpha$-mannosidase $(\square)$, and $0.1 \mathrm{U} / \mathrm{ml} \beta$-mannosidase $(\triangle)$. (B) The $\mathrm{IC}_{50}$ value for $\alpha$-glucosidase inhibition varied depending on the concentration of $\alpha$-glucosidase and the time of ceftezole pretreatment. Different concentrations $(1,2,4$, and $6 \mathrm{U} / \mathrm{ml})$ of $\alpha$-glucosidase were treated with ceftezole $(10 \mu \mathrm{M})$ for $1 \mathrm{~h}$. (C) Pretreatment effect of ceftezole. $\alpha$-Glucosidase $(1 \mathrm{U} / \mathrm{ml})$ was pretreated with ceftezole $(10 \mu \mathrm{M})$ for $0-120 \mathrm{~min}$ in phosphate buffer [50 $\mathrm{mM}(\mathrm{pH} 6.7)]$ at $30^{\circ} \mathrm{C}$. After pretreatment, PNP- $\alpha$-glucopyranoside was added to the mixture to initiate the enzyme reaction. $\mathrm{IC}_{50}$ values were determined by quantifying the amount of PNP liberated. (D) Double reciprocal plots of the inhibition kinetics of yeast $\alpha$-glucosidase by ceftezole. Following ceftezole treatment for $1 \mathrm{~h}$ at $30^{\circ} \mathrm{C}, 50 \mu \mathrm{l} \alpha$-glucosidase $(10 \mathrm{U} / \mathrm{ml}) \mathrm{was}$ treated with a mixture of each $50 \mu 1$ of the designated concentration of PNP- $\alpha$-glucopyranoside to initiate the enzyme reaction.

concentration required for $50 \%$ inhibition $\left(\mathrm{IC}_{50}\right.$ ) was $2.1 \times 10^{-6} \mathrm{M}$ $(2.1 \mu \mathrm{M})$ (Fig. 2A). $\alpha$-Glucosidase activity was reduced by ceftezole in a dose-responsive manner. The $\mathrm{IC}_{50}$ values for other glycolytic enzymes including $\alpha$-mannosidase, $\beta$ mannosidase, and $\beta$-glucosidase, were $4.1 \times 10^{-6} \mathrm{M}(4.1 \mu \mathrm{M})$, $2.2 \times 10^{-5} \mathrm{M}(22.0 \mu \mathrm{M})$ and $3.3 \times 10^{-5} \mathrm{M}(33.0 \mu \mathrm{M})$, respectively. We next examined the effects of ceftezole on $\alpha$-glucosidase inhibition (Fig. 2B and C). Following the addition of $2 \mathrm{mM}$ glucose to the reaction mixture, the $\mathrm{IC}_{50}$ value increased $>5$-fold, indicating that ceftezole either acts as an analog of glucose or binds to the glucose-binding site of $\alpha$-glucosidase. Fig. $2 \mathrm{~B}$ shows the effect on $\mathrm{IC}_{50}$ values when the amount of $\alpha$-glucosidase in the reaction mixture was raised from 1.0 to 6.0 units $/ \mathrm{ml}$. During the reaction, the $\mathrm{IC}_{50}$ value was increased from $2.2 \times 10^{-6} \mathrm{M}(2.2 \mu \mathrm{M})$ to $3.0 \times 10^{-5} \mathrm{M}$ $(30.0 \mu \mathrm{M})$. The $\alpha$-glucosidase inhibitory activity of ceftezole was increased by preincubating ceftezole with $\alpha$-glucosidase (Fig. 2C). When the substrate $(1 \mathrm{mM})$ and ceftezole $(10 \mu \mathrm{M})$ were added simultaneously, the $\mathrm{IC}_{50}$ was $\sim 3.5 \times 10^{-5} \mathrm{M}$ $(35.0 \mu \mathrm{M})$. This value was decreased 17.5 -fold $\left(\sim 2.0 \times 10^{-6} \mathrm{M}\right)$ when $\alpha$-glucosidase was treated with ceftezole at $30^{\circ} \mathrm{C}$ for $1 \mathrm{~h}$ before the enzyme reaction. Double-reciprocal plots of $\alpha$-glucosidase kinetics with ceftezole revealed that $\alpha$-glucosidase activity was also inhibited noncompetitively when the enzyme was pretreated with ceftezole $(10 \mu \mathrm{M})$ for $1 \mathrm{~h}$, with a $\mathrm{K}_{\mathrm{i}}$ value of $5.78 \times 10^{-7} \mathrm{M}(0.578 \mu \mathrm{M})$ (Fig. 2D).
Ceftezole exhibits an in vivo anti-diabetic profile. To confirm the effectiveness of ceftezole in an in vivo model, we analyzed whether or not ceftezole treatment decreased oral blood glucose levels in STZ-induced, diabetic C57BL/6NKist mice. Using GlucoDoctor, we determined the blood glucose levels of STZ-induced animals and considered mice with blood glucose levels $>250 \mathrm{mg} / \mathrm{dl}(266.7 \pm 15.8 \mathrm{mg} / \mathrm{dl})$ to be diabetic. Thereafter, these animals received ceftezole $(30 \mathrm{mg} / \mathrm{kg})$ one time per day for 14 days, and oral glucose levels were immediately assessed. Following ceftezole treatment, blood glucose levels decreased by as much as $30 \%(195.3 \pm 22.4 \mathrm{mg} / \mathrm{dl})$ compared to control animals (Fig. 3A). These results indicate that ceftezole inhibits the blood glucose increase that occurs following glucose uptake.

To determine how ceftezole affects the expression of various proteins, we performed RT-PCR of some biomarkers that are involved in diabetes. From the blood cells of STZinduced control or ceftezole-treated mice before OGTT, total RNA was isolated and extracted. After isolation of mRNA, RT-PCR was carried out as described in Materials and methods. As shown in Fig. 3B, mRNA expression levels of GSK-3, PPAR- $\gamma$ and UCP-3 were slightly decreased compared to that of the internal control GAPDH. The expression levels of other biomarkers for diabetes, including aldose reductase and PTP-1B, were not significantly changed by ceftezole treatment. Collectively, these data show that ceftezole exhibits anti-diabetic activity in vivo as well as in vitro. 
(A)

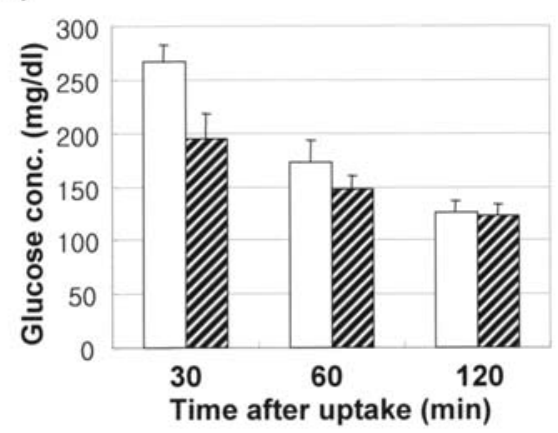

(B)

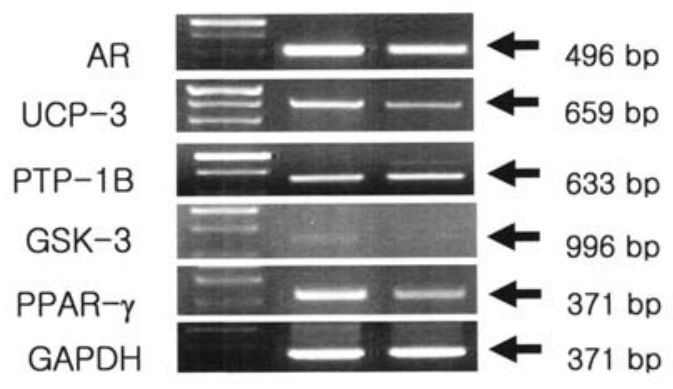

Figure 3. Ceftezole decreases blood glucose levels in vivo. (A) An STZ-induced animal model showed that ceftezole exhibits anti-hyperglycemic effects in vivo. The detailed procedure is described in Materials and methods. Briefly, after 20 days of STZ injections, ceftezole or vehicle was given intraperitoneally ( $30 \mathrm{mg} / \mathrm{kg} / \mathrm{day}$ ) every day for 14 days. Twenty-four hours after the final ceftezole treatment, the remaining mice were subjected to an oral glucose tolerance test as described previously (11). The means and standard errors were generated and significant differences were determined by the Student's t-test. Significance was established at $\mathrm{p}<0.05$. White bars, vehicle; hatched bars, ceftezole-treated. (B) mRNA expression patterns following ceftezole treatment in STZ-induced diabetic mice before OGTT. Primers are listed in Materials and methods. Tissues were lysed with TRIzol and collected supernatants were used for RT-PCR.

\section{Discussion}

Glycosidases, which are located in the brush-border surface membrane of intestinal cells (12), are essential for proper carbohydrate digestion (13). These enzymes are known to be adaptive and are specifically stimulated by certain dietary sugars. Carbohydrates have been shown to increase glucose metabolism in diabetic patients. Therefore, it is recommended that diabetic patients avoid simple carbohydrates (e.g., sucrose, maltose) in favor of polysaccharide alternatives $(14,15)$.

Glycosidase inhibitors are important tools for studying the mechanisms of action of glycosidases and are also prospective therapeutic agents for some degenerative diseases, including diabetes, viral attachment, and cancer $(16,17)$. Some researchers have reported that oral administration of specific $\alpha$-glucosidase inhibitors can effectively improve hyperglycemia as well as diabetic complications (18).

Acarbose is a pseudo-tetrasaccharide consisting of an unsaturated cyclitol unit that is a potent competitive inhibitor of $\alpha$-glucosidase. Acarviosine-glucose has been shown to be a potent inhibitor of baker's yeast $\alpha$-glucosidase that inhibits $\alpha$-glucosidase activity 430-fold stronger than acarbose (19). Other anti-diabetic agents derived from natural plant sources, including Myrcia multiflora, Aralia elata, Beta bulgaris, and Kochia scoparia, are currently being investigated in clinical trials (20).

In performing high-throughput screening for $\alpha$-glucosidase inhibitors, we recently identified the semi-synthetic antibiotic ceftezole (Fig. 1), as a potentially potent compound. The current study confirmed that ceftezole is a reversible and noncompetitive inhibitor of yeast $\alpha$-glucosidase with a $\mathrm{K}_{\mathrm{i}}$ value of $5.78 \times 10^{-7} \mathrm{M}$ when the enzyme mixture is pretreated with ceftezole. More importantly, an STZ-induced diabetic mouse model revealed that ceftezole can be clinically used to treat diabetic symptoms, suggesting that the present agent can be used in diabetic complications $(10,21,22)$.

Cephem antibiotics are very important for the treatment of a variety of bacterial infections and represent a new generation of $\beta$-lactam antibiotics (23). Ceftezole has an excellent anti-biological profile against a broad spectrum of organisms, including gram-negative bacteria (24). The antibiotic is produced by Streptomyces clavurigrus, Streptomyces limpanii, Streptomyces lactamdurans, Emericellopsis, and Paecilomyces sp., but these strains do not produce sufficient amounts for large-scale application. Therefore, the microbial production of ceftezole has been substituted with chemical synthesis, beginning with cephalosporin $\mathrm{C}$; however, use of this agent has resulted in minor immunotoxicity in mice (25).

We found that $\alpha$-glucosidase activity was inhibited by ceftezole in a dose-responsive manner (Fig. 2B). We concluded that ceftezole may bind to $\alpha$-glucosidase, and that $\alpha$-glucosidase inhibitory activity by ceftezole was increased by preincubating it with the enzyme (Fig. 2C). Comparison of the Dixon plots indicated that an $\sim 20$-fold-higher concentration of dialyzed ceftezole-treated $\alpha$-glucosidase was required to attain the same level of enzyme activity as dialyzed untreated $\alpha$-glucosidase (data not shown). These data suggested that the mechanism of action of $\alpha$-glucosidase inhibition may be reversible. Double reciprocal plots of $\alpha$ glucosidase with ceftezole revealed that this process was non-competitive when the enzyme was pretreated with ceftezole for $1 \mathrm{~h}$.

An in vivo STZ-induced diabetic model revealed that ceftezole may be clinically used for managing diabetic complications. We found that administration of ceftezole $(10 \mathrm{mg} / \mathrm{kg}$ ) decreased oral blood glucose levels by up to $30 \%$ compared to those of control-treated animals. Although we did not show the time course data, ceftezole treatment resulted in decreased glucose levels between 10 and $60 \mathrm{~min}$ of oral glucose administration. Together, these in vitro and in vivo assays revealed that ceftezole exerts its anti-diabetic activity by inhibiting $\alpha$-glucosidase and by decreasing blood glucose levels.

In conclusion, the above results suggest that ceftezole may potentially be clinically useful as a potent inhibitor of $\alpha$ glucosidase in patients with diabetes and other metabolic diseases. The inhibition studies described here provide useful information for designing new, potent glycosidase inhibitors. 
Yeast $\alpha$-glucosidase is known to be very different from mammalian digestive enzymes, indicating that ongoing research should focus on the inhibitory activity of ceftezole against mammalian intestinal $\alpha$-glucosidases. Studies to elucidate the molecular mechanisms of action of more potent ceftezole derivatives as well as potential synergistic effects of ceftezole and the previously reported $\alpha$-glucosidase inhibitor genistein (8) are currently underway. Further studies with ceftezole should be performed in primates to determine any possible in vivo side effects of this agent and, moreover, to overcome drug resistance in the event of longterm use.

\section{Acknowledgements}

This study was partially supported by a grant from BioGreen 21 Program, Rural Development Administration, Korea (S-H. L.).

\section{References}

1. Lebovitz HE and Banerji MA: Treatment of insulin resistance in diabetes mellitus. Eur J Pharmacol 490: 135-146, 2004.

2. Singleton JR, Smith AG, Russell JW and Feldman EL: Microvascular complications of impaired glucose tolerance. Diabetes 52: 2867-2873, 2003.

3. Leslie RD and Pozzilli P: Type I diabetes masquerading as type II diabetes. Possible implications for prevention and treatment. Diabetes Care 17: 1214-1219, 1994.

4. Newell AM: Genetics for targeting disease prevention: diabetes. Prim Care 31: 743-766, 2004.

5. Rich SS and Concannon P: Challenges and strategies for investigating the genetic complexity of common human diseases. Diabetes 51: S288-S294, 2002.

6. Herold KC, Baumann E, Vezys V and Buckingham F: Expression and immune response to islet antigens following treatment with low doses of streptozotocin in $\mathrm{H}-2 \mathrm{~d}$ mice. J Autoimmun 10: 17-25, 1997.

7. Harris F, Chatfield L, Singh J and Phoenix DA: Role of calpains in diabetes mellitus: a mini review. Mol Cell Biochem 261: 161-167, 2004.

8. Lee DS and Lee S-H: Genistein, a soy isoflavone, is a potent alpha-glucosidase inhibitor. FEBS Lett 501: 84-86, 2001.

9. Segel IH: Enzyme Kinetics: Behavior and Analysis of Rapid Equilibrium and Steady-State Enzyme System. Wiley, New York, pp100-202, 1975.
10. Tam J, Rosenberg L and Maysinger D: INGAP peptide improves nerve function and enhances regeneration in streptozotocin-induced diabetic C57BL/6 mice. FASEB J 18: 1767-1769, 2004

11. Kawa JM, Taylor CG and Przybylski R: Buckwheat concentrate reduces serum glucose in streptozotocin-diabetic rats. J Agric Food Chem 51: 7287-7291, 2003.

12. Winchester B and Fleet GW: Amino-sugar glycosidase inhibitors: versatile tools for glycobiologists. Glycobiology 2: 199-210, 1992.

13. Bischoff H: Pharmacology of alpha-glucosidase inhibition. Eur J Clin Invest Suppl 3: 3-10, 1994.

14. Hirsh AJ, Yao SY, Young JD and Cheeseman CI: Inhibition of glucose absorption in the rat jejunum: a novel action of alphaD-glucosidase inhibitors. Gastroenterology 113: 205-211, 1997.

15. Caspary WF: Sucrose malabsorption in man after ingestion of alpha-glucoside hydrolase inhibitor. Lancet 1: 1231-1233, 1978.

16. Gruters RA, Neefjes JJ, Tersmette M, de Goede RE, Tulp A, Huisman HG, Miedema F and Ploegh HL: Interference with HIV-induced syncytium formation and viral infectivity by inhibitors of trimming glucosidase. Nature 330: 74-77, 1987.

17. Dennis JW, Laferte S, Waghorne C, Breitman ML and Kerbel RS: Beta 1-6 branching of Asn-linked oligosaccharides is directly associated with metastasis. Science 236: 582-585, 1987.

18. Fonseca V: Clinical significance of targeting postprandial and fasting hyperglycemia in managing type 2 diabetes mellitus. Curr Med Res Opin 19: 635-641, 2003.

19. Wehmeier UF and Piepersberg W: Biotechnology and molecular biology of the alpha-glucosidase inhibitor acarbose. Appl Microbiol Biotechnol 63: 613-625, 2004.

20. Li WL, Zheng HC, Bukuru J and De Kimpe N: Natural medicines used in the traditional Chinese medical system for therapy of diabetes mellitus. J Ethnopharmacol 92: 1-21, 2004.

21. Anjaneyulu M and Chopra K: Fluoxetine attenuates thermal hyperalgesia through 5 -HT1/2 receptors in streptozotocininduced diabetic mice. Eur J Pharmacol 497: 285-292, 2004.

22. Pospisilik JA, Martin J, Doty T, Ehses JA, Pamir N, Lynn FC, Piteau S, Demuth HU, McIntosh CH and Pederson RA: Dipeptidyl peptidase IV inhibitor treatment stimulates beta-cell survival and islet neogenesis in streptozotocin-induced diabetic rats. Diabetes 52: 741-750, 2003.

23. Noto T, Nehashi T, Endo H, Saito M and Matsubara S: Ceftezole, a new cephalosporin C derivative. I. In vitro and in vivo antimicrobial activity. J Antibiot 29: 1058-1070, 1976.

24. Nishida M, Murakawa T, Kamimura T, Okada N, Sakamoto H, Fukada S, Nakamoto S, Yokota Y and Miki K: In vitro and in vivo evaluation of ceftezole, a new cephalosporin derivative. Antimicrob Agents Chemother 10: 1-13, 1976.

25. De Sarro A, Ammendola D, Zappala M, Grasso S and De Sarro GB: Relationship between structure and convulsant properties of some beta-lactam antibiotics following intracerebroventricular microinjection in rats. Antimicrob Agents Chemother 39: 232-237, 1995. 